\title{
Post-Replication Modification
}

National Cancer Institute

\section{Source}

National Cancer Institute. Post-Replication Modification. NCI Thesaurus. Code C26376.

Post-Replication Modification involves covalent alteration of DNA after replication, e.g., methylation at either $\mathrm{A}$ or $\mathrm{C}$ bases within a particular DNA sequence. $(\mathrm{NCI})$ 